\title{
Social Enterprises in Brazil: Socially Produced Knowledge Versus Social Innovation.
}

\author{
Edileusa Godói-de-Sousa I,Valdir Machado Valadão Júnior²
}

\begin{abstract}
This study investigated whether socially produced knowledge in social ventures in Brazil has promoted social innovation and local development. The research is exploratory and descriptive, and was developed in two stages. At first, the sample group was composed of 378 projects selected from the mapping of Solidarity Economic Enterprises, conducted by the National Secretary of Solidarity Economy (Secretaria Nacional de Economia Solidária). The sample was surveyed to verify the main characteristics of these enterprises. After that, interviews were conducted with key managers in a sample of 32 projects. The results indicate challenges in the long path of favoring dynamic learning, with a generation of knowledge from the collective experiences of socialization: there is a lack of joint discussion and a predominance of individualized learning actions.
\end{abstract}

Keywords: social entrepreneurship; knowledge management; social innovation.

Faculdade de Gestão e Negócios, Universidade Federal de Uberlândia, Av. João Naves de Ávila, n 2121 - Campus Sta. Mônica - Bloco F, Bairro Sta. Mônica, CEP: 38408-I44, Uberlândia, MG - Brazil. 'Phone: +55 34 32327275. E-mail: edileusagodoi@uol.com.br 2Phone: +55 34 32394 I32. E-mail: valdirjr@ufu.br. 


\section{Introduction}

The constant changes that society undergoes have been confirmed by a number of factors that can be clearly identified and located in time. These include the praise of selfemployment, advances in civil society organization and the deepening of the globalization process, which motivates a quest for continuous innovation and new opportunities for social and economic participation.

As a result, people excluded from the labor market seek their recognition and their ability to work and undertake. For Culti $(2002$, p. 3), these are the people who have taken initiatives, "[...] with expectations to meet their needs and open new paths in life, through the use of their own strengths and resources, associating with others and organizing themselves into groups, associations and cooperatives.

According to Moreira, Vidal and Farias (2003) these selfmanaged production arrangements, based on cooperation, the notion of a fair market and sustainable locally developed integrated associations, signal a Third Way as a counterpoint to the dominant economic system characterized by the traditional capitalist structure.

The main experiments in this sense have been multiplying in various parts of the world for some time, as an expression of a social movement that has sociological and political characteristics. With a proposition of changing the capitalist structure, not necessarily revolutionary, but with reformist features, this social movement has been called Social Entrepreneurship.

The typology covering social enterprises can be very broad and diverse, either because of conceptual vagueness, or as a result of the innovative creativity of the entrepreneurs. In this range, you can find from self-managed enterprises to informal groups of people precariously associated in a common effort to generate income and survive the harsh conditions of poverty and exclusion. In this broad context, formal organizations, cooperatives and associations dedicated to the so-called "inclusive business" bloom.

Experiencing such changes, however, does not always make it possible to assess the scope and importance of the historical moment society might be witnessing. In this context, the impact of the transformations occurring in the social environment led to reflection about the importance of socially produced knowledge through these social interactions and its application to the processes of social innovation. This reflection has generated the interest that made us try to establish a correlation of the following issues: social entrepreneurship, learning, knowledge management and social innovation.
Therefore, the aim of this study was the analysis of socially produced knowledge in social enterprises in Brazil. More specifically, we were concerned about establishing a relationship between knowledge generation and the social innovation originated from management and interaction modes with the environment in which these social enterprises are inserted.

\section{Theoretical Reference}

\section{Organizational Learning and Knowledge Management}

For Antonello (2005), learning is a dynamic concept that encompasses continuous change and integrates the individual, group and organizational levels.

At the individual level, the learning process is composed of changes that occur in individual behavior, resulting not only from maturation, but from his or her interaction with the context (Abbad \& Borges-Andrade, 2004). "Learning comes from the tension between old and new knowledge and also from the transformation of this knowledge in the memory of an individual" (Antonello, 2005, p. 23).

From these definitions we see that organizational learning is related to various factors, as defined by Antonello (2005): Organizational learning is a continuous process of appropriation and generation of new knowledge at the individual, group and organizational levels, involving all forms of learning - formal and informal - in the organizational context, based on a dynamic of reflection and action on problem situations [...].

Thus, in relation to notions of organizational learning and the management mode known as knowledge management, it is possible to establish some considerations. First, there is the consideration that they line up and are an anti-response to the moment when stability is lost and seek to learn from it. Second, there is the consideration that because they have learned they are able to respond more promptly to changes arising from the loss of stability.

In this view, organizations should be structured internally to maximize all knowledge learned. In this sense, knowledge management would satisfy the critical needs for adaptation, survival and competence in face of a disrupted and constantly changing environment. Essentially, it would incorporate organizational processes that seek a combination where there is synergy between data and the ability to process information through the use of information technology and would spread the ability to create and innovate constantly in their members (Malhotra, 20II). 
More explicitly, organizational learning is the way in which organizations build, supplement and organize knowledge around their activities and within their culture, adapting and developing an efficient organization. Learning organizations would be those that purposely build structures and strategies that enhance and maximize organizational learning (Dodgson, 1993).

Therefore, there must be a connection between the concepts of organizational learning and knowledge management. The latter will structure what has been learned by the organization so that it can be made available to other members and generate core competencies and / or the so-called dynamic learning. Dynamic learning represents, in the concept of Fleury and Fleury (1995), the observance of some points in the organization that are related to what Schein (1992) proposes as basic assumptions, shared by a group, and on which social practices are based. Thus, the implementation or the existence of dynamic learning in an organization presupposes what Senge, Ross, Kleiner, Roberts and Smith (1999) called deep change.

Seen in this light, the term organizational learning seems to approach the purpose of Berger and Luckmann (2000), in defining reality as a social construct. For these authors, everyday life is the reality constructed and interpreted by men, i.e., reality is, over time, subjectively endowed with sense for these men as they form a coherent world.Therefore, learning is not built as an end, but as a means of integration among men. So, learning recognized as a means of integration between men presupposes an understanding of reality, time, space, the human condition, human activity and human relationships that enables a dynamic learning. It also seems true that, in this perspective, the models assume the connotation of a parameter, i.e., they must be framed to reality.

However, the notion of learning in organizations, seen from the perspective of knowledge management, seems to take a pragmatic approach, as it is oriented towards the building of core competencies with the objective of generating competitive advantages, i.e., the organization should structure what they "know" in order to differentiate themselves from their competitors in order to achieve a specific goal, the market. In other words, the dynamic of learning has a strategic concept and is implemented as a means to an end: to establish competencies.

Under this view, the term organizational learning can be understood as an attribute of knowledge management. Another aspect of conciliation of the two concepts is that knowledge management should be understood as an effort to apprehend organizational learning. It is not constituted as a formal body within the organizational structure and, before anything else, should be a principle that pervades the organization.

\section{Socially Produced Knowledge and Social Innovation}

Recognizing learning and knowledge as socially produced epistemologies of social enterprises management entails the belief that one moves toward the so-called social innovation and its prerequisites: improving community and citizen's life inside and outside the workplace.

So if social entrepreneurs become sympathetic in the process of emancipation in (and of) societies, they are producers of knowledge by interacting with various cultures through solidarity actions and exchange of knowledge and information. Thus, they are creating new processes and consequently innovating their relations.

New paradigms and benchmarks begin to show a potential to satisfy social needs. The concept of social innovation comes as a starting point for building a new model to meet the social demands regarding diversity and human unity, and contribute to the promotion of equality in a post-modern society. (Farfus \& Rocha, 2007, p. 19th).

According to Farfus and Rocha (2007), this new configuration of the relationship with society highlights the urgent need for finally ending the myth that in the social area there is no innovation. "Social innovation can be defined as a set of processes, products and methodologies that enables improved quality of life and decreases other inequalities." (Farfus \& Rocha, 2007, p. 9)

From this concept, we must reflect on the conditions and historical moments that let flourish the issue of social innovation, no longer tied to methodologies and imposed processes but, as Farfus and Rocha (2007, p. 29) point out, on a view sustained by democratic and ethical principles. These principles seek the inclusion and promotion of all those diminished by the social chasm present in different societies, solidarity in knowledge-emancipation and a networked multicultural environment.

Thus, to understand what is involved in a living, social and complex self-producing environment, which, according to Capra (1995), is characterized by the development of connections in the form of networks, requires us to 'think holistically'.

So, if we perceive the patterns involving human relationships, structures and possibilities, we will have a new vision of social interactions, and social systems will need to be designed and planned in a continuous manner. And increasingly, using socially produced knowledge, i.e., one that occurs from a spiral of knowledge based on personal commitment and several conversions between explicit and implicit knowledge, involves the individual, the group, the organization and the 
environment. This model consists of four modes of knowledge conversion processes (Nonaka \& Takeuchi, 1997):

I. Socialization (tacit knowledge to tacit knowledge): exchange of knowledge that leads to the creation of shared mental models or technical skills. Therefore, an individual can gain knowledge from observation, imitation and practice when interacting with others;

2. Externalization (tacit knowledge to explicit knowledge): articulation of tacit knowledge into explicit concepts, usually caused by dialogue, reflection and combination of methods of induction and deduction. This form of expression comes through analogies, metaphors, concepts, hypotheses or models ;

3. Combination (explicit knowledge to explicit knowledge): systematizing concepts into a knowledge system, which involves the production of new knowledge or new meanings from the reconfiguration of existing information, with the help of search mechanisms, classification, categorization and information interpretation;

4. Internalization (explicit knowledge to tacit knowledge): incorporation of explicit knowledge in tacit knowledge, or learning by doing. For that to happen, it is necessary for the subject to express his or her own experience.

It is in this scenario that the great contribution of social innovations is allocated, the search for new ways of thinking, relating, creating structures, patterns and connections in different dimensions that add value to all. In this sense, the issue of innovation is configured as an instrument of social transformation.

In this line of thought, we may say, according to Fleury (200I), that the innovation process has the effect of rebuilding social relation systems and features that replicate those systems. Thus, we can speak of a social innovation from the moment that changes and innovations alter the processes and social relations, changing existing power structures.

In organizational settings, according Farfus and Rocha (2007), social innovation can only occur, market oriented or not, when there is organizational learning. Still, according to these authors, when it comes to social innovation, besides the new addition and contribution to knowledge building and dissemination with the society in view, based on organizational learning, we should include "the commitment to the transformation, recognition and valuing of the knowledge of the other, the principle of sustainable development, the pursuit of multiculturalism in the process and of methodologies for empowerment of all individuals." (Farfus \& Rocha, 2007, p. 32).
Particularly, this work had an interest in the epistemology underlying knowledge management and development of organizational learning in social enterprises, with a view to promoting social innovation.

\section{Methodology}

\section{Characteristics of the study}

Regarding its nature, this study is classified as applied research, because besides involving located truths and interests, it aims to generate knowledge for practical application (Silva \& Menezes, 2000). It is also an organizational, exploratory and descriptive research, in that it aims to structure currently scattered and diffuse information about socially produced knowledge through the interaction of the actors of the social enterprises surveyed and their relation to social innovation, aiming to subsidize possible interventions and the development of further studies in the field of management of these enterprises in Brazil.

Studies have been conducted that added to the analysis of secondary and primary qualitative data, to allow the identification of the main characteristics of the process of knowledge generation in these social enterprises. According to Richardson (1999), qualitative research enables the description of the complexity of a particular phenomenon, the analysis of the interaction of certain variables and the understanding and classification of dynamic processes experienced by social groups.

\section{Research Trajectory: subjects, data collection and analysis}

The empirical research was structured in two phases that are inter-related: In the first phase, the sample group was composed of 378 social enterprises. These enterprises were selected from the mapping of ESS, Solidarity Economic Enterprises (Empreendimentos Econômicos Solidários), conducted by SENAES / MTE, National Secretariat of Solidarity Economy (Secretaria Nacional de Economia Solidária), in partnership with the FBES, Brazilian Forum of Solidarity Economy (Fórum Brasileiro de Economia Solidária). The sample was the subject of a survey to identify the productive associations and whose leaders had shown willingness to participate.

In the second stage, from a sample of 32 enterprises, we examined through interviews with key managers of these enterprises whether socially produced knowledge through the interaction of the actors' associations has promoted productive social innovation and local development as a result. To identify the key characteristics of social enterprises surveyed and the process of knowledge generation and its 
application in social innovation we used as sources of analysis the mechanisms of institutional governance - structure, planning, councils, communication, control and evaluation in the enterprises.

Specifically, we sought to identify factors, resources, actions, interventions that can contribute to the generation of knowledge in the context of social enterprises, especially in relation to the process of social innovation, taking as reference the concepts of Knowledge Management, Organizational Learning and Social Innovation explained in the previous topic. Based on this theoretical framework and the opinions and perceptions of the respondents, we sought to answer the following questions:

I. How are Knowledge Management and Organizational Learning embedded in the context of the social enterprise? 2. How does the process of intra and / or inter organizational learning occur?

3.What are the results for social innovation already achieved? 4. What are the current challenges? How are they being overcome?

For the analysis and interpretation of the data, we opted for the method of triangulation in order to minimize the noise intrinsic to each source and ratify or rectify the information (Triviños, 1992). The analysis of the corrected data is anchored by the theoretical framework used.

\section{Profile of the object of study social enterprises}

The 32 social enterprises that participated in the second phase of this study had the following profile: the average time of existence of these enterprises is 18 years, the oldest being 48 years old. Most originated from community development initiatives of the Church and Social Movements, others from the motivation / need of a group of people of their community or even from the encouragement and support of the State.

Together, the 32 initiatives studied directly benefit more than 8,000 people. Most are concentrated in the Northeast, followed by the South and Southeast, and fewer in the north. Almost half of these enterprises have operations in both urban and rural areas. The most frequent activities are agriculture, extraction, fishing, crafts, collecting and recycling and, to a lesser extent, services in health and education.

The products and services are aimed predominantly at local places, with a minority reaching national and / or international markets. The main places are fairs, shops and industries. Intermediaries and the Internet are also cited.
These social enterprises are driven primarily by the need to generate income for the immediate care of the basic needs of those involved, who are people and communities within the lower socioeconomic strata of the Brazilian social structure.

In Table I below, the projects that were part of the second phase of the research are identified. The names of the enterprises surveyed were replaced by numbers so that the identities of these are preserved.

We were able to verify some striking trends presented during the data analysis about the descriptive profile of the leaders of the 32 social enterprises surveyed.

Most of the leaders of these enterprises are mature people, since 21 (65.7\%) are between 40 and 60 years old, 8 $(25.0 \%)$ are between 25 and 36 years old, and $3(9.3 \%)$ are more than 70 years old. The concentration in the intermediate age group is similar to that observed in the private sector, since in both sectors management positions require more experience.

Regarding the education level of the respondents, 13 (40.5\%) have college degrees and 4 (12.5\%) were college dropouts (predominantly in the areas of Administration, Pedagogy, Psychology, Arts, Agriculture, Biology and Accounting), 10 (31.5\%) with a high school diploma and 5 (15.5\%) with incomplete primary education.

Such data shows the existence of a relationship between education level and position in the enterprise, i.e., the higher the education level, the higher the position held at the institution. The following statement illustrates this:

[...]By knowing how to write a little, you know, they want me to be president, or secretary, or treasurer. And they also trust me, right? So these are the positions I always assume. I'm taking Pedagogy. l'm in the fourth semester. (Interviewee Association 26 - BA).

Regarding time, in years, that interviewed leaders are in the enterprises, 15 (47.0\%) responded that they have participated 5 to 10 years in the association, II (34.3\%) 10 to 20 years and $6(18.7 \%)$ said they have participated for over 30 years. If you add the percentages of those who have participated 10 to 20 years with those who have for over 30 years, we have that $53 \%$ of the leaders of the enterprises surveyed have been in the associations for over 10 years. This shows a persistent and constant participation of these leaders, indicating that it is criterion, albeit informal, to assume the presidency. 


\begin{tabular}{|c|c|c|c|c|c|c|c|}
\hline REGION & ASSOCIATION & STATE & MUNIC. & AREA & YEAR & No.ASSOC. & $\begin{array}{l}\text { PROD./ } \\
\text { SERV. }\end{array}$ \\
\hline \multirow{8}{*}{$\begin{array}{l}\text { South } \\
8 \\
\text { Associations }\end{array}$} & Association I & RS & Jaboticaba & Urban & 1990 & 120 & health \\
\hline & Association 2 & RS & Canguçu & Rural & 1988 & 700 families & family farming \\
\hline & Association 3 & RS & Dois Irmãos & Urban & 1994 & 21 & Recic. household waste \\
\hline & Association 4 & RS & $\begin{array}{l}\text { Quinze de } \\
\text { Nov. }\end{array}$ & Urban & 1991 & 23 & Craft \\
\hline & Association 5 & PR & Foz do Iguaçu & Urban & 1999 & 200 & Special Education \\
\hline & Association 6 & PR & $\begin{array}{l}\text { Francisco } \\
\text { Beltrão }\end{array}$ & Urban and Rural & 1995 & 123 & Collection and recycling \\
\hline & Association 7 & SC & $\begin{array}{l}\text { Paulas, São } \\
\text { Franc. do Sul }\end{array}$ & Urban and Rural & 1998 & 21 families & $\begin{array}{l}\text { Mariculture (cultivation of } \\
\text { mussels) }\end{array}$ \\
\hline & Association 8 & SC & Jaraguá do Sul & Urban and Rural & 1999 & 23 & Craft \\
\hline \multirow{8}{*}{$\begin{array}{l}\text { Southeast } \\
8 \\
\text { Associations }\end{array}$} & Association 9 & RJ & Maré & Urban & 1996 & 32 & Craft. garment \\
\hline & Association 10 & SP & $\begin{array}{l}\text { Espírito Santo } \\
\text { do Turvo }\end{array}$ & Urban & 1991 & 30 & accessories \\
\hline & Association II & SP & Barra do Turvo & Urban and Rural & 1996 & 102 families & dolls \\
\hline & Association 12 & ES & Ponto Belo & Urban and Rural & 1997 & 120 & Toys \\
\hline & Association 13 & ES & $\begin{array}{l}\text { Venda Nova } \\
\text { do Imigrante }\end{array}$ & Urban and Rural & 1979 & 123 & family farming \\
\hline & Association 14 & RJ & $\begin{array}{l}\text { Bom Jesus do } \\
\text { Itabapoana }\end{array}$ & Urban and Rural & 1986 & 50 & family farming \\
\hline & Association 15 & MG & Pirapora & Urban & 1996 & 62 & Craft, Embroidery \\
\hline & Association 16 & MG & $\begin{array}{l}\text { Carmo do } \\
\text { Paranaíba }\end{array}$ & Urban & 1980 & 53 & sewing \\
\hline \multirow{4}{*}{$\begin{array}{l}\text { North } \\
4 \\
\text { Associations }\end{array}$} & Association 17 & AM & $\begin{array}{l}\text { Alto Rio } \\
\text { Negro }\end{array}$ & Rural & 1992 & $\begin{array}{l}17 \text { indigenous } \\
\text { counity }\end{array}$ & $\begin{array}{l}\text { Basketry, pottery, medicinal } \\
\text { plants }\end{array}$ \\
\hline & Association 18 & AM & Manaus & Urban and Rural & 1984 & 56 & Craft \\
\hline & Association 19 & AM & Lábrea & Urban and Rural & 1997 & 460 & Agriculture and extraction \\
\hline & Association 20 & AP & Macapá & Urban and Rural & 1989 & 130 & Craft \\
\hline \multirow{12}{*}{$\begin{array}{l}\text { Northeast } \\
12 \text { Associa- } \\
\text { tions }\end{array}$} & Association 21 & BA & Tucano & Urban and Rural & 1999 & 16 & Sheep and goats \\
\hline & Association 22 & BA & Guanambi & Rural & 1990 & 160 & $\begin{array}{l}\text { Agriculture and small } \\
\text { livestock }\end{array}$ \\
\hline & Association 23 & BA & $\begin{array}{l}\text { Feira de } \\
\text { Santana }\end{array}$ & Urban and Rural & 1997 & 25 & $\begin{array}{l}\text { Dolls, Jewelry, Leather } \\
\text { goods }\end{array}$ \\
\hline & Association 24 & BA & Valente & Urban and Rural & 1980 & 750 & Training of farmers \\
\hline & Association 25 & BA & Caetité & Urban and Rural & 1985 & 1200 & family farming \\
\hline & Association 26 & $\mathrm{BA}$ & Caetité & Rural & 1999 & 180 & agriculture \\
\hline & Association 27 & BA & Tucano & Urban & 1998 & 68 & Craft \\
\hline & Association 28 & PE & Gravatá & Urban & 1962 & 290 & $\begin{array}{l}\text { Cultural activities, craft and } \\
\text { training }\end{array}$ \\
\hline & Association 29 & $\mathrm{PE}$ & Camutanga & Urban and Rural & 1999 & 167 & Agriculture and livestock \\
\hline & Association 30 & PE & $\begin{array}{l}\text { Fernando de } \\
\text { Noronha }\end{array}$ & Urban & | 1991 & 18 & Craft \\
\hline & Association 31 & $\mathrm{PI}$ & Simões Piauí & Urban & 1999 & 28 & Apiculture \\
\hline & Association 32 & MA & $\begin{array}{l}\text { Santa Luzia do } \\
\text { Paruá }\end{array}$ & Rural & 1998 & 28 & Apiculture \\
\hline
\end{tabular}

Table I. Enterprises that participated in the second phase of the research. Data based on the research results.

ISSN: 07 I8-2724. (http://www.jotmi.org)

Journal of Technology Management \& Innovation (C) Universidad Alberto Hurtado, Facultad de Economía y Negocios. 
When comparing these data to the age of respondents, it is clear that many began to act in the association's activities when they were young and remain until today. This leads to the assumption that most of the leaders of the associations surveyed have extensive working experience and associative participation. This occurred not only in the associations that were surveyed, but also in other associations, for 8 (25.0\%) of respondents reported that before joining the association they had held jobs in other institutions (manager of another non-governmental organization, the environmental movement, social pastoral etc.).

\section{Analysis of results}

\section{Knowledge Management and Organizational Learning in the context of social enterprises.}

The context of social enterprises surveyed showed a variety of forms, backgrounds and concerns. However, you can see some similarities in these association initiatives. Generally, they are experiences linked to a specific territorial framework (a neighborhood, a city, a region) that attempt, through their practices, to cope with local problems. They articulate different sectors of society to have their projects funded. However, several of them still remain quite marked by their precarious situations.

We detected that there is a long way to go to bring about a learning dynamic in these projects, with the construction of knowledge from the collective experiences of socialization. We found that in more than half of the enterprises surveyed, that's not happening. Some examples were reported by respondents such as: lack of debate, individualized learning actions and lack of preparation to understand the significance of associating.

What has happened in these projects is the participation in a timely manner, in courses, lectures and meetings with other entities, favoring only those who are in leadership positions and who rarely spread this knowledge among the other members, claiming lack of interest of these.

Thus, training is the responsibility of each member and this creates a fragmented and individualized learning process, which can lead members to not recognize the values that they represent in this type of organization. The testimony below highlights this:

[...] we really lack the association spirit, of one helping the other, growing with each other. (Interviewee Association 30 - PE).

To meet this challenge, Valadão Júnior (2003) recommends moments of reflection and qualification that precede the formation of this type of organization. For the author, this can be accomplished through contact with other institutions that have the same proposal. Besides generating organizational learning, this can lead to a solidarity network.

\section{The process of intra and / or inter organizational learning}

For the process of intra organizational learning, the respondents stressed the importance of participation of members in the decisions of these enterprises. These occur mainly in the work plan defined in a general meeting or at a meeting of members of the collective and when choosing the directors of the association.

All respondents reported that members have access to records and information of the enterprise and accountability reports are given in assemblies and meetings of the collective members. However, some have complained about the lack of interest of associates in participating in the decisions of the association. They recognized that these members lack awareness about what an association really means:

Honestly, working in association is very difficult, each one has a mind of his own, there are many to give advice and few to help. There are many critics, but nobody helps. (Interviewee Association 10 - SP).

With this, some interviewees pointed to the need for complementary actions from their own government to empower, to educate and raise the level of awareness on the concept and practice of membership in such organizations as may be identified in the following statement:

[...] the State organs who coordinate this [...] must do things that strengthen the production concept, the marketing concept, and before this the concept of association, because they do not truly know what it is to be in an association. (Interviewee Association 27 - BA).

Valadão Júnior (2003) suggests that this type of organization must, at the same time, concern for the quality of its products/services and with cost-efficiency-effectiveness relations, as well as with the formation of its members, thereby producing continuous transformations from its learning systems.

However, only 3 of the 32 projects surveyed seem to be searching for personnel training other than the board itself. Moreover, this training is still limited to courses and lectures directed to the immediate needs of the organization, failing to contemplate a constant long-term preparation, as can be seen below:

ISSN: 07 I8-2724. (http://www.jotmi.org) 
Besides the meetings we have, lectures, [they] participate in seminars $[. .$.$] to arouse the curiosity of people to organize$ themselves better. (Interviewee Association 19 - AM).

We have had several courses there in the community, professionalization courses [...] knowledge, skills... (Interviewee Association 22 - BA).

The big challenge is always training undoubtedly [...] we do not have anything specifically focused on training like, agents for managing [...] I believe it might be important to have an even more specific process. (Interviewee Association II - SP).

Therefore, training is the responsibility of each member and it ends up creating individualized learning, i.e., the dynamic of learning is fragmented. We do not see an organizational dynamic of learning, the cognitive system is functional, the primary relationships are restricted to celebration times and, finally, the organization is not reciprocal regarding their community.

The cognitive system is functional, not establishing a dynamic of learning between subjects in the organization: there is no constant quest for innovation; training is focused on technical learning, on individualized training. Organizational objectives are declared but not are shared by all members. The organizational structure used in most enterprises surveyed does not favor communication between members of the organization and, thus, the relations are not of primary order.They are impersonal.

For Laville (2006), voluntary action to join these initiatives should be rooted in the reference of a democratic social bond, where the actions of each member cannot be disconnected from the social bond that motivated them. Accordingly, for França Filho and Laville (2004), the effectiveness of these initiatives unfolds in a relationship of interdependence, involving different logics of action and mobilizing various forms of legitimacy.

Thus, the development ability of social enterprises depends, increasingly, on their intra and / or inter-organizational relationships, from which one can establish a dynamic of learning.

Although most enterprises surveyed had not sought interorganizational articulation, about $40 \%$ of these initiatives have sought to partner with other institutions, to cover the deficiency that individual learning generates in organizational learning. The following reports show the search for this interaction:
[...] We sought partners, a government institute, there is an NGO that is working with education right? We have invited them to be partners offering preparation courses for these people [...]. Besides the meetings we have lectures, we participate in seminars [...] every general meeting has an agenda, encouraging the people, showing what this reality of associations is, so it will arouse people's curiosity, to get better organized, right? (Interviewee Association 19 - AM).

[...] We started to understand what the association was when we began to participate in the labor movement, we started to get projects started to understand what it really was to be a part of community, the association, then we started grow a little more. (Interviewee Association 22 - BA).

Respondents of the enterprises that have sought this interaction, expressed that leadership is exercised in the organization based on collective learning. Thus, discussions, creativity and the experience of each one is essential to develop the work. The notions of learning to learn and discussing as a group are ratified in the interview transcript excerpt below: Today, thank God, the association is with a group that is well understood, we do things all scheduled, arranged, agreed in the group, right? So thank God it has worked like that. This group has made changes harmoniously. (Interviewee Association 19 - AM).

However, it seems that under these collective endeavors, things are articulated with the different perceptions and values that shape the daily lives of each associate. This may imply that attitudes such as "sharing" responsibilities and duties, which require trust and commitment from people traits that characterize associations - are not as present in all the different people involved. Perhaps because, there is still a lack of understanding on the part of members of what the practice of associating really is. The statements below demonstrate this finding:

Our culture here is still far from what an association is. If I say that in these eight years we managed to establish an association, l'm not telling the truth, right? (Interviewee Association 19 - AM).

[...] there is a great lack of associative spirit, one helping the other, growing with each other. (Interviewee Association 30 - PE).

Thus, the objective possibility of pursuing a full reason is restricted in these organizations. They do not emphasize the political cognitive system, the primary relationships among their members are restricted as a consequence and both democracy and the dynamics of learning are compromised.

ISSN: 07 I8-2724. (http://www.jotmi.org) 
At the same time, if the issues related to the welfare of the members are not resolved internally, then this compromises the effectiveness dimension and reciprocity with the community in which they are involved. In these organizations, the market enclave and the goal of marketing overlap the welfare of both their members and the community to which they belong.

\section{The results of the process of learning and knowledge generation for social innovation.}

We found that in II (34.3\%) of the 32 enterprises surveyed, educational work has been privileged, so that people recognize themselves as bearers of rights. These initiatives are typical of the North and Northeast regions of the country, originating from social movements. The transcribed reports below show how these developments have provided empowerment to people.

[...]we have been organizing ourselves, conducting regional assemblies, discussing practical education in the region. It is like this that we can therefore discuss education as reality. So with that we have been increasingly getting stronger. (Interviewee Association 17 - AM).

We began discussing our participation in society, the importance and also the lack of respect for society itself with women [...] over time, about 5 years, women began to be aware. (Interviewee Association 25-BA).

[...] The main objective of the association is the integral formation of the human being in the political, economic, social, cultural and moral sector [...] We as an institution [...] we also live in this policy of organizing, one of the slogans of the movement is " only the organized people save the people." (Interviewee Association 28 - PE).

Although in this perspective there is an orientation towards learning in order to disseminate social welfare, the results of this research show that in more than half of the enterprises surveyed $(65.6 \%)$ the ability to generate knowledge for coping with social problems is still small. In fact, their concern may be focused on the goal of creating core competencies in the enterprises, in order for them to differentiate themselves in their markets. (Fleury \& Fleury, 200I).

\section{Current challenges and how they have been overcome}

The organizations surveyed live between the need for survival of its members and a proposed significance of group action, i.e., the tension between increasing productivity to increase profit and having space for discussion, debate and reflection. Thus, some of the main challenges of these initiatives are: a dynamic approach to learning, solidarity among members and reciprocity of their actions to the community in which they operate.

We could recognize in most of these social ventures a divergent reality from what was expected from a work and income organization with solidarity basis. Among them, the shared values are close to individualism and exploitation of members by the ruling coalition.

We were unable to verify actions, in most enterprises, demonstrating collective dynamic learning. They do not seek innovations; they expect them to come in aid from the government. The leaders are accommodated, dependent and react to the institutional environment. They do not have a policy of training associates, most are illiterate and dissemination of knowledge occurs because of tradition, so this knowledge is static. Finally, there is little reciprocity in relation to the community in which they live; the actions are restricted to benefits provided to the families of members. And for those enterprises that have sought an interaction with the community, their efforts to draw attention to more general social issues through their actions is still small and restricted to the local community.

Such initiatives have the challenge to create favorable conditions for socio-economic organization and collective selfmanagement for the socially produced knowledge in the context of these enterprises to promote social innovation. To overcome these challenges, Fischer (2002) reinforces the importance of partnerships by point out that the development capacity of social enterprises depends, increasingly, on their intersectoral relations. However, when building an alliance or partnership, Austin (200I) and Fischer (2002) warn of the need to be aware of the objectives of each partner, to assess risks and identify the factors that justify the formation of said partnership. Before beginning a partnership that aims to be lasting and productive, it is important to assess what the partners have in common. It is necessary to evaluate why they want to work in partnership, which values they have, what the goals and expected benefits for them are and finally they must be clear how and with what each can contribute. We add to this the need for trust between the actors involved, without which the possibility of collaboration would be compromised.

The results of this research show that about $40 \%$ of social enterprises have sought to establish partnerships with other institutions. However, alliances have occurred mostly with the government (especially local), by need for more material aid or financial resources, training and technical support provided by municipal departments to better promote the organization's actions, than to create favorable conditions to learn and generate knowledge for the promotion of social innovation. 


\section{Final Thoughts}

The 32 social enterprises surveyed have some characteristics in common. According to the research objectives, they should be highlighted. The relating of their components to them is spontaneous; their work alone is significant, the requirements are minimal and are restricted in almost all cases to a statute based on legislation and, as it seems, the rules of operation only obey a local legal requirement and are not shared by all the members, so they do not guarantee their commitment to the enterprise.

But on the other hand, despite being freely connected to the social enterprise, seeing meaning in what they produce, defining the time to work, there is no dynamic of learning. The cognitive system is functional. Finally, such enterprises do not seek to develop, despite claiming plans and there being statutory goals in this sense, effective and reciprocal actions with their communities. Among them, we do not observe solidarity.

Despite the associates worrying with product quality and cost efficiency, they are experts. There is no social planning of activities of the class. There is no debate, no shared vision of the organization, no leadership with the intention of learning with the associates and passing on the knowledge to other associates instead of just representing them. Finally, we do not recognize shared values that show solidarity among members. They have two clear objectives: securing their space and surviving through the marketing of their products.

Thus, they do not favor a dynamic learning because the innovations are individualized. There is no training plan that involves all members, although this is one of the goals outlined in the statutes of these enterprises. The objectives are not shared, so learning is timely and favors those who are ahead of the organization, perhaps because there is no engagement. They were not prepared, as aforementioned, to understand the significance of associations.

We also observed that the leaders in these organizations do not have the objective of disseminating knowledge among their members. When activity planning occurs, it does not have the idea of joint discussions and deliberations. A small group makes the decisions. The work is done in isolation and the members act as specialists in their activities. There is little exchange of information among members of the organization.

Therefore, we conclude that although the concepts of learning, knowledge management and social innovation constitute important references of current practices of social enterprises in Brazil, there is still a great heterogeneity in the use of these constructs and of their main references. As they say in the academic world, these are approaches that are still in the construction phase for the reality of these projects.

Still, the absence of indicators and further studies hinder, if not prevent, the comparison of results of socially produced knowledge and the measurement of the impact on social innovation in the context of these enterprises.

From these preliminary findings, we can reach one conclusion: it is not easy to propose models or uniformity of actions to disseminate learning in the context of third sector organizations aimed at social innovation. Each one has its own logic and before any analysis, it is necessary to recognize the individuals who participate in them and their goals and thus understand the organization's goals and its learning dynamic.

\section{References}

ABBAD, G. S., \& Borges-Andrade, J. E. (2004). Aprendizagem humana em organizações de trabalho. In:Zanelli,J. C. BorgesAndrade J. E., \& Bastos A.V. B. (Eds.). Psicologia, organizações e trabalho no Brasil. Porto Alegre:Artmed.

ANTONELLO, C. S. (2005). A metamorfose da aprendizagem organizacional: uma revisão crítica. In: Ruas R., Antonello C. S., \& Boff L. (Eds.).Aprendizagem organizacional e competências. Porto Alegre: Bookman.

AUSTIN, J. E. (200I). Parcerias - Fundamentos e Benefícios para o Terceiro Setor. São Paulo, Editora Futura.

BERGER, P. L., \& Luckmann, T. (2000).A construção social da realidade. Petrópolis:Vozes.

CAPRA, F. (1995). O ponto de mutação. São Paulo: Cultrix.

CULTI, M. N. (2002). O Cooperativismo Popular no Brasil: Importância e Representatividade. Anais do $3^{\circ}$ Congresso Europeo de Latinoamericanistas. Amsterdam-Holanda, 3.

DODGSON, M. (1993). Organizational learning: a review of some literatures. Organization Studies, I4(3), 375-394.

FARFUS, D., \& Rocha, M. C. de S. Inovação Social: um conceito em construção. (2007). In: Inovações Sociais, Coleção Inova; vol. II, Curitiba: SESI/SENAI/IEL/UNINDUS, 13-34.

FISCHER, R. M.( 2002). O desafio da colaboração: práticas de responsabilidade social entre empresas e Terceiro Setor. São Paulo: Gente. 
FLEURY, S. (200I). Observatório da inovação social.Anais do Congresso Internacional Del Clad Sobre La Reforma Del Estado Y De La Administración Pública, Buenos Aires, 9.

FLEURY, M.T. L.. \& Fleury,A. (200I). Construindo o conceito de competência. Revista de Administração Contemporânea. Edição Especial, I83-196.

FLEURY, A., \& Fleury, M.T.L. (1995). Aprendizado e inovação organizacional: as experiências do Japão, Coréia e Brasil. São Paulo:Atlas.

FRANÇA FILHO, G. C., \& Laville, Jean-Louis. (2004). A Economia Solidária: uma abordagem internacional. Porto Alegre: Editora da UFRGS.

LAVILLE, J. (2006). Ação pública e economia: um quadro de análise. In: França Filho G. C. (Ed.). Ação pública e economia solidária: uma perspectiva internacional. Porto Alegre: editora da UFRGS.

MALHOTRA, Y. Information, Knowledge \& Window: whose concerns? http:www.brint.com/wwwboard/messages/l85l. html. [Accessed May 20, 20II]

MOREIRA, V. ;Vidal, F. A. B.; Farias, I. Q. (2003). Empreendedorismo Social e Economia Solidária: Um Estudo de Caso da Rede de Desenvolvimento Local Integrado e Sustentável da Comunidade do Grande Bom Jardim. Anais do XXXVIII Assembleia do Conselho Latino-Americano de Escolas de Administração. Lima, Peru.

NONAKA, I., \& Takeuchi, H. (1997). The knowledge creating company. New York: Oxford University Press.

RICHARDSON, R. J. (1999). Pesquisa social: métodos e técnicas. São Paulo:Atlas.

SCHEIN, E. (1992). Organizational culture and leadership. San Francisco: Jossey-Bass.

SENGE, P. M., Ross, R. B., Kleiner, A., Roberts, C., Smith, J. (1995). A quinta disciplina: caderno de campo: estratégias e ferramentas para construir uma organização que aprende. Rio de Janeiro: Qualitymark.

SILVA, E. L., \& Menezes, E. M. (2000). Metodologia da Pesquisa e Elaboração de Dissertação. Florianópolis: LED/UFSC.

TRIVIÑOS,A. N.S. (1992). Introdução à pesquisa em ciências sociais: a pesquisa qualitativa em educação. São Paulo:Atlas.
VALADÃO JÚNIOR., V. M. (2003). Bases Epistemológicas e modo de gestão em organizações geradoras de trabalho e renda.. Tese (Doutorado em Engenharia de Produção) - Programa de Pós-Graduação em Engenharia de Produção da Universidade Federal de Santa Catarina, Florianópolis. 